\title{
Efekti socijalnoga konteksta na povezanost uporabe medija s nekim aspektima razvoja djece
}

\author{
Tena Velki \\ Fakultet za odgojne i obrazovne znanosti, Sveučilište J.J. Strossmayera u Osijeku, Hrvatska
}

\author{
Ivana Duvnjak
}

Filozofski fakultet, Sveučilište J.J. Strossmayera u Osijeku, Hrvatska

\section{Sažetak}

Cilj je istraživanja provjeriti povezanost učestalosti uporabe različitih medija (gledanje televizije, igranje računalnih igrica i korištenje interneta) s aspektima kognitivnog (školski uspjeh) i socijalno-emocionalnog razvoja (impulzivnost, afektivna empatija, broj prijatelja i vršnjačka prihvaćenost). Također, htjeli su se provjeriti moderatorski efekti roditeljskog prisustva i društva prijatelja na navedene povezanosti. U istraživanju je sudjelovalo 880 učenika od petog do osmog razreda. Podaci o impulzivnosti, afektivnoj empatiji i izloženosti medijima prikupljeni su samoprocjenama. Učenici su dali još podatke o broju najboljih prijatelja, osjećaju prihvaćenosti i školskom uspjehu.

Povezanosti učestalosti korištenja različitih medija i aspekata kognitivnog i socijalnoemocionalnog razvoja uglavnom su niske. Najistaknutije su negativne povezanosti s afektivnom empatijom, i to osobito vrijeme provedeno igrajući igrice, te pozitivna povezanost s impulzivnošću, posebice s korištenjem interneta. Nešto je manja povezanost učestalosti korištenja medija s brojem prijatelja i vršnjačkom prihvaćenosti, dok je učestalost gledanja televizije blago negativno povezana sa školskim uspjehom.

Testirani su i moderacijski efekti socijalnog konteksta na povezanosti učestalosti korištenja medija i aspekata razvoja. Dobiveni su efekti vrlo mali i uglavnom vezani za odnos gledanja televizije i školskog uspjeha te učestalosti igranja računalnih igrica i odnosa s vršnjacima. Dobivena je negativna povezanost vremena gledanja televizije i školskog uspjeha samo kod onih koji to čine u društvu (roditelja i prijatelja), dok kod onih koji gledaju sami nije značajno različita od nule. Isto tako, pozitivan odnos vremena provedenog igrajući videoigrice i broja prijatelja nešto je manji kod onih koji to čine u društvu prijatelja te su blago pozitivni efekti učestalosti igranja igrica na vršnjačku prihvaćenost kod onih koji igraju sami, dok su blago negativni kod onih koji igraju u društvu roditelja. Svi efekti socijalnog konteksta i korištenja medija na aspekte razvoja djece vrlo su slabog intenziteta, a interpretirani su okviru Modela različite podložnosti utjecaju medija (DSMM; Valkenburg i Peter, 2013).

Ključne riječi: mediji, roditeljska prisutnost, vršnjaci, socio-emocionalni razvoj, kognitivni razvoj

Tena Velki, Fakultet za odgojne i obrazovne znanosti, Sveučilište J.J. Strossmayera u Osijeku, Ulica cara Hadrijana 10, 31000 Osijek, Hrvatska. E-pošta: tena.velki@gmail.com 


\section{Uvod}

Brojna su istraživanja potvrdila kako izloženost djece medijima može značajno utjecati na različite aspekte djetetova razvoja, posebice socijalnog i emocionalnog, $i$ u to u pozitivnom i negativnom smjeru (npr. Wilson, 2008). Tijekom vremena utjecaj medija pokazao je suptilan, ali kumulativan efekt (Prot i Gentile, 2014), stoga izloženost različitim medijima predstavlja rizični čimbenik za razvoj problema $\mathrm{u}$ ponašanju. Neka djeca i adolescenti provode više vremena gledajući televiziju nego što su u školi (Marini, Dane i Bosacki, 2006), dok druga istraživanja pokazuju kako djeca i adolescenti u prosjeku gledaju televiziju oko tri sata dnevno (AEM/UNICEF, 2014; Bilić, 2010; Brug i sur., 2012). Istraživanja u Hrvatskoj dodatno su pokazala da $94 \%$ djece od 10 do 14 godina gleda televiziju svaki dan, a najčešće gleda filmove i televizijske serije, posebice one "za odrasle", koje sadrže elemente uzbuđenja (Ilišin, 2003). Međutim, komparativna su istraživanja provedena na djeci iz pet europskih zemalja (Belgija, Njemačka, Grčka, Mađarska i Norveška) pokazala značajan učinak zemlje djetetova porijekla na vrijeme provedeno uz televizijske ekrane i računalo (Verloigne i sur., 2015). Polovica tinejdžera igra računalne igrice svaki dan (Lenhart i sur., 2008) te provede u prosjeku između jedan i tri sata igrajući se na računalu (Bilić, 2010; Verloigne i sur., 2015). Kada je u pitanju uporaba interneta, istraživanje u SAD-u pokazalo je da se $97 \%$ adolescenata od 12 do 18 godina koristi internetom (UCLA Internet Report, 2003), a polovica njih se njime koristi svaki dan kako u SAD-u (Lenhart, Madden i Hitlin, 2005), tako i u Hrvatskoj (Hrabri telefon i Poliklinika za zaštitu djece grada Zagreba, 2008). Gledajući sve medije zajedno, prosječno američko dijete, od 8 do 18 godina, svaki dan provede 6 sati i 21 minutu koristeći se nekim medijem za zabavu (Roberts, Foehr i Rideout, 2005), a to je i ujedeno najduže vrijeme koje dijete provede u nekoj aktivnosti dnevno, izuzev spavanja (Roberts, 2000).

Školska djeca s dijagnozom ADHD-a više gledaju televiziju i dva je puta veća vjerojatnost da imaju televizor u svojoj sobi, a čak i kada nemaju televizor u sobi, češće ga gledaju nego njihovi vršnjaci (Acevedo-Polakovich, Lorch i Milich, 2007). $\mathrm{Na}$ temelju učiteljskih procjena dobivena je pozitivna povezanost problema pažnje i impulzivnosti s količinom gledanja televizije kod učenika četvrtih i petih razreda (Levine i Waite, 2000). Na temelju samoprocjena djece količina vremena gledanja televizije također je povezana $\mathrm{s}$ niskom ustrajnosti i visokom impulzivnosti (Anderson i Collins, 1988). Međutim, nije jasno je li količina vremena ili televizijski sadržaj odgovoran za ovakvu povezanost. Igranje računalnih igrica može omogućiti optimalne uvjete učenja jer pruža trenutnu povratnu informaciju, što je vrlo motivirajuće za djecu s ADHD-om, posebice za onu s dominantnim simptomima impulzivnosti (Chan i Rabinowitz, 2006). Eksternalno nagrađivanje prisutno je gotovo stalno tijekom igranja igrica, pogotovo neposredno prije i u trenutku kada dijete reagira $u$ igri (Houghton i sur., 2004). Također, povećava aktivaciju i pobuđenost što može poboljšati izvedbu. Što se tiče vremena korištenja interneta i igranja igrica, veći broj sati provedenih u ovim aktivnostima mogu dodatno pojačati 
sklonost prema impulzivnoj, brzoj i usmjerenoj reaktivnosti što je u suprotnosti s drugim aktivnostima (sport, glazba i umjetnost), koje mogu pomoći u razvijanju samokontrole, pažnje i socijalizacije (Weiss, Baer, Allan, Saran i Schibuk, 2011). S druge strane, pokazalo se kako je kod adolescenata s ADHD-om došlo do poboljšanja u svakodnevnom funkcioniranju mozga, pozornosti, impulzivnosti i hiperaktivnosti nakon igranja igrica (SonyPlay Station) 40 puta po sat vremena (Wright, 2001).

U medijima se prikazuju sadržaji koji predstavljaju nasilje ili ponašanje koje je usmjereno činjenju štete drugima, no također se prikazuju i ponašanja usmjerena pomaganju drugima (Smith i sur., 2006). Moguće je da gledanje prosocijalnog ponašanja u medijima može pomoći socijalizaciji djece jer posredno može dovesti do oblikovanja prosocijalnih spoznajnih struktura koje uključuju prosocijalno ponašanje, empatiju i druge pozitivne osobine, uključujući samoregulaciju (Gentile, Groves i Gentile, 2014). Ukupno vrijeme gledanja televizije i omiljenih televizijskih serija pozitivno je povezano s agresijom (Padilla-Walker, Coyne, Collier i Nielson, 2015), no također gledanje prosocijalnog televizijskog sadržaja izravno predviđa niže razine agresije i više razine prosocijalnog ponašanja prema obitelji do dvije godine kasnije (Padilla-Walker i sur., 2015). Nadalje, potvrđena je negativna povezanost između korištenja medija s agresivnim sadržajima i empatičkom brigom za druge (Funk, 2005). Djeca koja puno vremena provode na internetu pokazuju veći pad u socijalnoj i psihološkoj dobrobiti (Kraut i sur., 1998).

Glavna je razvojna promjena u razdoblju predadolescencije i adolescencije uspostavljanje novih veza s vršnjacima. Kada rabe računalo, djeca su najčešće sama, a interakciju s vršnjacima najčešće ostvaruju na društvenim mrežama (Subrahmanyam, Kraut, Greenfield i Gross, 2000). Pojedinci od svojih prijatelja očekuju prisnost i podršku, čija kvaliteta znatno opada ako je orijentirana i ostvarena samo u virtualnom svijetu. Korištenje interneta smanjuje vrijeme koje djeca i mladi provode uživo i na taj način djeluju na pojavu neželjenih osjećaja, kao što su razočaranje, nezadovoljstvo i osjećaj izoliranosti i usamljenosti (Shaw i Gant, 2002). Djeca koja ostvaruju veći broj "elektroničkih prijateljstava" u odnosu na stvarna prijateljstva s vršnjacima također pokazuju i pad u interpersonalnim sposobnostima (Subrahmanyam i sur., 2000). Učenici koji se rijetko koriste internetom, u odnosu na one koji se njime služe često, imaju bolje odnose s prijateljima i majkama (Sanders, Field, Diego i Kaplan, 2000). Upotreba komunikacije u virtualnom svijetu u malim mjerama nema štetan učinak na razvoj djece, no kada prijeđe optimalnu granicu, postaje problem i može uzrokovati neželjene promjene u napretku djeteta. Usamljena djeca sklapaju više prijateljstva na internetu, kojima pokušavaju ostvariti emocionalnu podršku, a koja izostaje u stvarnom svijetu, no to im uzrokuje smetnje u svakodnevnom funkcioniranju (Morahan-Martin i Schumacher, 2003). Longitudinalno istraživanje pokazalo je da se povećava učestalost korištenja interneta u situacijama kada dolazi do smanjenja komunikacije s obitelji i smanjenja društvenog kruga (Kraut i sur., 1998). Društvene mreže pružaju drugačije načine 
komunikacije u kojima se pojedincima omogućuje razvoj osjećaja prihvaćenosti te pronalazak pojedinaca koji pružaju razumijevanje. Moguće je objašnjenje da mlade koji su usamljeni i koji imaju slabe veze s drugima u stvarnom životu privlači internet zbog mogućnosti interakcija koje pruža (Subrahmanyam i Lin, 2007).

Elektronički mediji dugo su vremena bili kritizirani zbog svog potencijalno negativnog utjecaja na djecu (Bushman i Huesmann, 2006; Stipp i Milavsky, 1988). Rezultati ranijih istraživanja (Singer, 1980) pokazuju kako djeca, kao aktivni korisnici medija, kognitivno pasivna, ne mogu obrađivati televizijske sadržaje te stoga ni učiti iz njih. Stoga ne čudi da se javlja zabrinutost zbog toga na koji način izlaganje različitim medijima utječe na kognitivni razvoj i akademsko postignuće. Zimmerman i Christakis (2005) su na uzorku od gotovo 1800 djece utvrdili umjeren efekt između uspješnosti računanja i čitanja u dobi od šest ili sedam godina i gledanja televizije, pri čemu svaki dodatni sat proveden ispred televizije prije treće godine štetno utječe na kasnije sposobnosti čitanja i računanja, dok u dobi od tri do pet godina može biti korisno za poznavanje čitanja i kratkoročno pamćenje. S druge strane, jasno je kako djeca mogu i učiti putem medija; na primjer, postoje televizijski programi kojima je cilj podučavanje akademskim ili socijalnim vještinama te mogu imati dugoročan pozitivan utjecaj (Zill, 2001). Slično je i s računalnim igricama. Istraživanja pokazuju kako postoji negativna povezanost između igranja računalnih igrica i školskog uspjeha (npr. Burgess, Stermer i Burgess, 2012). Učitelji češće navode kako učenici koji puno vremena provode igrajući računalne igrice iskazuju poteškoće pozornosti te imaju slabiji san, što utječe na školski uspjeh. Što više vremena učenik provodi igrajući igrice, manje vremena mu ostaje za pisanje zadaća, učenje i svakodnevne školske aktivnosti (Drummond i Sauer, 2014). Međutim, pronađeni su i pozitivni učinci igranja računalnih igrica, poput bržeg procesiranja sekundarnih vizualnih podražaja, bolje okulomotorne koordinacije ruka-oko, analitičkog mišljenja, razvoja logičkih i matematičkih sposobnosti (Thomas i Brown, 2009). Temeljiti pregled istraživanja o obrazovnim mogućnostima računalnih igrica nije pronašao dokaze kako igrice imaju osobite koristi za učenje, odnosno igranje igrica bez podrške nastavnika (ili odrasle osobe) nije dovoljno da bi predstavljalo alat za učenje (O'Neil, Wainess i Baker, 2005).

Model različite podložnosti utjecaju medija (The Differential Susceptibility to Media Effects Model-DSMM; Valkenburg i Peter, 2013) opisuje tri tipa uvjetovanih varijabli pod kojima je utjecaj medija više ili manje prisutan. To su razvojno, dispozicijski i socijalno podložne varijable, koje postoje prije pojave utjecaja medija, a mogu djelovati ili kao prediktori ili kao moderatori uporabe medija.

Razvojna podložnost odnosi se na varijable koje definiraju razinu djetetova socijalnog, emocionalnog i kognitivnog razvoja. U skladu s tom razinom određeni mediji i njihovi sadržaji imaju jači ili slabiji utjecaj na različite aspekte djetetova razvoja. Pojedinci na određenoj razvojnoj razini preferiraju medijski sadržaj koji je njima zanimljiv i razumljiv, odnosno koji je optimalan za njihovu razvojnu razinu (Valkenburg i Cantor, 2000). 
Dispozicijska podložnost odnosi se na varijable koje predstavljaju predispoziciju za korištenje medija, kao što su: neuroticizam, agresivnost, traženje uzbuđenja, stavovi, motivacija i raspoloženja i slično (Krcmar, 2009; Oliver, Kim i Sanders, 2006) te one moderiraju utjecaj medija na tri različita načina. Kod pojedinaca koji imaju tendenciju više tražiti i upotrebljavati medije, barem u određenoj mjeri, ta je tendencija vezana uz njihovu dispoziciju, odnosno crte ličnosti (Klapper, 1960), njihov razvojni stupanj (Valkenburg i Cantor, 2000) te norme koje prevladavaju u društvenim skupinama kojima pripadaju (McDonald, 2009).

Socijalna podložnost definira se kao svi faktori socijalnog konteksta koji mogu utjecati na djetetovu uporabu i odgovornost prilikom uporabe medija, a to na mikrorazini uključuje roditelje, prijatelje, vršnjake, na mezorazini najčešće školski sustav, a na makrorazini kulturalne norme i vrijednosti djeteta usvojene unutar obitelji i škole (Bronfenbrenner, 1979; Valkenburg i Peter, 2013). Učinak medija je transakcijski, odnosno osim samog sadržaja i vremena provedenog uz medije bitna je i interakcija pojedinca s jednom ili više drugih osoba (posebice roditelja, prijatelja i bliskih osoba) za vrijeme korištenja medija. Roditelji i vršnjaci mogu ograničiti ili potaknuti izloženost određenim televizijskim programima ili igricama. Isto tako, škole, organizacije ili vlade mogu zabraniti ili potaknuti pristup određenim internetskim stranicama. Konačno, norme i vrijednosti u nekom društvu mogu onemogućiti ili omogućiti pojedincima da se koriste određenim medijima.

Prema tome, model DSMM objašnjava zašto su neki ljudi podložniji utjecaju medija, kako i zašto mediji utječu na te pojedince te kako se utjecaj medija može pojačati ili smanjiti.

Iako postoje brojna istraživanja utjecaja medija, malo je onih koji su uzeli u obzir socijalni kontekst tijekom korištenja medija, a gotovo da nema istraživanja koja ispituju moderacijsku ulogu socijalno podložnih varijabli (Valkenburg i Peter, 2013). Socijalni konteksti na mikro, mezo i makrorazini snažni su u poticanju ili inhibiranju uporabe medija (Klapper, 1960; McDonald, 2009). Društveni se utjecaji javljaju na dva načina: namjerno, kada roditelji, braća i sestre, vršnjaci, škole ili institucije ograničavaju ili reguliraju korištenje medija (Jordan, 2004; Nathanson, 2001), ili otvorenije, kroz norme koje prevladaju u obitelji, vršnjačkim skupinama ili supkulturama (McDonald, 2009). Socijalni kontekst može moderirati učinak medija tijekom zajedničkog korištenja određenih medija. Roditelji mogu namjerno utjecati na poruku koja se prenosi medijima, ako npr. objašnjavaju sadržaj i poruku koju mediji prenose djetetu (Nathanson, 2001). Također, tijekom zajedničke se uporabe medija može dogoditi i "emocionalna zaraza" (McDonald, 2009) jer su korisnici medija vrlo osjetljivi na tuđe stavove, raspoloženja i emocionalne reakcije, pa stoga vlastite kognicije, emocije i uzbuđenje mogu pojačati ili smanjiti ovisno o stanju osobe s kojom se zajednički koriste medijem.

Cilj je istraživanja bio provjeriti povezanost učestalosti korištenja različitih medija (gledanje televizije, igranje računalnih igrica i korištenje interneta) s nekim aspektima kognitivnog (školski uspjeh) i socijalno-emocionalnog razvoja 
(impulzivnost, afektivni aspekt empatije, broj prijatelja i vršnjačka prihvaćenost) te provjeriti razlikuju li se te povezanosti ovisno o vrsti medija kojim se učenik koristi. Također, željeli smo provjeriti efekt socijalnog konteksta (roditeljska prisutnost ili društvo prijatelja) na navedene povezanosti, odnosno, u skladu s DSMM modelom, ima li prisutnost roditelja i prijatelja moderatorsku ulogu u povezanosti uporabe medija i nekih aspekta razvoja djeteta.

\section{Metoda}

\section{Sudionici}

U istraživanju su sudjelovali učenici viših razreda šest osnovnih škola $\mathrm{s}$ područja Grada Osijeka. Ukupno je sudjelovalo 880 sudionika, učenika od petog do osmog razreda osnovne škole ( $48 \%$ dječaka i $52 \%$ djevojčica). Prosječna je dob učenika iznosila 12.8 godina $(S D=1.15)$, a raspon godina kretao se od 10 do 16 godina starosti.

\section{Instrumenti}

Skala učestalosti izloženosti medijima (UM; Velki, 2012) sastoji se od tri pitanja vezana uz količinu vremena koje dijete provedi uz medije. Sudionik treba zaokružiti broj ispred odgovora koji se odnosi na njega. Odgovori su se bodovali od 1 do 5, gdje 1 označava da sudionik ne upotrebljava određeni medij, a 5 je označavalo maksimalno vrijeme korištenja medija. Za učestalost gledanja televizije 1 označava da dijete ne gleda televiziju, 2 - gleda do 3 sata dnevno, 3 - do 5 sati dnevno, 4 - do 10 sati dnevno i 5 - više od 10 sati dnevno. Za učestalost igranja računalnih igrica i korištenje interneta 1 označava da dijete ne igra računalne igrice ili ne se koristi internetom, 2 - igra igrice/upotrebljava internet do 3 sata tjedno, 3 - igra igricelupotrebljava internet do 5 sati tjedno, 4 - igra igrice/upotrebljava internet do 10 sati tjedno i 5 - igra igrice/upotrebljava internet više od 10 sati tjedno. Skala je namijenjena učenicima od petog do osmog razreda. Također je ovom skalom ispitan i socijalni kontekst u kojem je korišten određeni medij. Sudionik je za svaku vrstu medija (televizija, računalo $\mathrm{i}$ internet) trebao označiti tko je najčešće prisutan $\mathrm{s}$ učenikom dok upotrebljava određeni mediji (roditelji/odrasli skrbnici, prijatelji/vršnjaci/braća/sestre ili sam).

Upitnik empatije (Ivanović i Buško, 2008) mjeri stupanj empatije koji se odnosi na uživljavanje u emocionalna stanja druge osobe i razumijevanje njezina položaja na temelju percipirane ili zamišljene situacije u kojoj se ta osoba nalazi. Konstruiran je za djecu osnovnoškolskog uzrasta (od petog do osmog razreda). Pri tome se afektivni aspekt empatije definira kao doživljavanje emocija kao reakcije na emocionalno stanje druge osobe, a kognitivni aspekt kao razumijevanje stanja druge osobe te spoznaju kako nešto što se događa drugom pojedincu može djelovati na 
njega. Sudionici istraživanja trebaju pored svake tvrdnje zaokružiti broj koji ih najbolje opisuje. Raspon odgovora kreće se od 0, što znači uopće se ne odnosi na mene, do 4 u potpunosti se odnosi na mene. Upitnik empatije ima ukupno 22 čestice i možemo ga podijeliti na dva faktora koji se daju interpretirati u skladu s početnim pretpostavkama o afektivnoj i kognitivnoj empatiji. Međutim, u našem istraživanju dvije čestice (Grozno mi je kad netko gazi cvijeće ili bilje.; Rijetko primijetim da je u parku netko tko se nema s kim igrati.) iz Upitnika empatije izrazito su utjecale na smanjenje pouzdanosti, a također su i pri konfirmatornoj faktorskoj analizi pokazivale niska zasićenja (manja od 0.3) te su stoga izbačene iz daljnje analize. Eksploratornom je faktorskom analizom (metoda glavnih komponenata, kosokutna rotacija) utvrđeno postojanje dvaju faktora (na temelju karakterističnog korijena i Scree-testa) koji objašnjavaju 32.8\% ukupne varijance, a korelacije između dvije komponente su niske $(r=.24, p<.01)$, što predstavlja problem prilikom korištenja ukupnog skalnog rezultata od 20 čestica. Konfirmatornom faktorskom analizom (ML metoda) potvrdili smo postojanje dvofaktorskog modela $\left(\chi^{2}=501, s s=169\right.$, RMSEA=0.074). Pouzdanost cijelog Upitnika empatije je $\alpha=.70(k=20)$, dok je za Supskalu afektivna empatija $(k=10)$ pouzdanost bila relativno visoka $\alpha=.79$, a za Supskalu kognitivna empatija $(k=10)$ pouzdanost je bila niska $\alpha=.43$. Pri daljnjoj analizi podataka odlučili smo uzeti samo Supskalu afektivne empatije, dok smo Supskalu kognitivne empatije isključili zbog niske pouzdanosti.

Skala impulzivnosti (Vulić-Prtorić, 2006) dio je šire Skale hiperaktivnostimpulzivnost-pažnja (HIP), namijenjene za procjenu hiperaktivnog i impulzivnog ponašanja te problema usmjeravanja pažnje. HIP skala sastoji se od 19 čestica koje opisuju najčešće simptome navedenih problema u djetinjstvu i adolescenciji, a koje se dijele na tri supskale: Skala hiperaktivnosti, Skala impulzivnosti i Skala pažnje. HIP je skala samoprocjene na kojoj sudionik na skali od 5 stupnjeva (od nikad do vrlo često) procjenjuje u kojoj su se mjeri ponašanja opisana u tvrdnjama kod njega javljala u posljednjih šest mjeseci. Raspon odgovora kretao se od 1 do 5, a rezultat se za svaku supskalu formirao na temelju aritmetičkih sredina određenih čestica te se teoretski kreće od 1 do 5. Namijenjena je djeci od petog do osmog razreda osnovne škole. U našem je istraživanju primijenjena samo Skala impulzivnosti, koja se sastoji od četiri čestice, a čija je pouzdanost iznosila Cronbach $\alpha=.72$.

Za prikupljanje demografskih karakteristika djeteta (dob, spol, razred) pripremljen je poseban obrazac. Također, putem ovog su obrasca prikupljeni i podaci vezani uz osjećaj vršnjačke prihvaćenosti (dvije čestice na skali Likertova tipa s tri stupnja (1 - nikad, 2 - ponekad, 3 - često), na kojima je učenik procijenio koliko se od strane vršnjaka osjeća prihvaćeno odnosno odbačeno), broj najboljih prijatelja koje učenik ima (gdje je učenik samo napisao koliko ima najboljih prijatelja) te školski uspjeh (koji se sastojao od šest ocjena: uspjeh iz hrvatskog jezika i matematike na polugodištu i kraju školske godine te opći uspjeh koji je učenik imao na polugodištu i na kraju školske godine). Pouzdanost varijable školski uspjeh iznosila je Cronbach $\alpha=.94$. 


\section{Postupak}

Uz dopuštenje odgovornih institucija i pismenu suglasnost roditelja i suglasnost djece, a nakon informiranja o općim ciljevima i svrsi istraživanja, podaci su prikupljani tijekom nastave u školama. Učenicima je jasno istaknuta dragovoljnost sudjelovanja i zajamčena povjerljivost podataka dobivenih $u$ istraživanju. Podaci su prikupljeni grupno, a njihovo je prikupljanje trajalo oko 45 minuta. Po završetku ispitivanja učenici su o problemima mogli razgovarati sa školskom psihologinjom i istraživačicama te su dobili kontakt elektroničke pošte za eventualna naknadna pitanja.

\section{Rezultati}

U Tablici 1. prikazani su deskriptivni podaci za mjerene varijable. Puni raspon odgovora dobiven je za gotovo sve mjerene varijable (izuzev školskog uspjeha i afektivne empatije), a koeficijenti asimetrije i spljoštenosti nisu prelazili +/- 2 .

Tablica 1. Prikaz deskriptivne statistike za mjerene varijable

\begin{tabular}{lccccccc}
\hline Varijable & $N$ & Min & Max & $M$ & $S D$ & $\begin{array}{c}\text { Koeficijent } \\
\text { asimetrije }\end{array}$ & $\begin{array}{c}\text { Koeficijent } \\
\text { spljoštenosti }\end{array}$ \\
\hline $\begin{array}{l}\text { Vrijeme provedeno gledajući } \\
\text { televiziju }\end{array}$ & 873 & 1.00 & 5.00 & 2.42 & 0.83 & 1.15 & 1.50 \\
$\begin{array}{l}\text { Vrijeme provedeno igrajući } \\
\text { računalne igrice }\end{array}$ & 873 & 1.00 & 5.00 & 2.78 & 1.41 & 0.37 & -1.17 \\
Vrijeme provedeno koristeći internet & 873 & 1.00 & 5.00 & 3.30 & 1.27 & 0.03 & -1.26 \\
$\begin{array}{l}\text { Impulzivnost } \\
\text { Afektivna empatija }\end{array}$ & 869 & 1.00 & 5.00 & 2.40 & 0.79 & 0.63 & 0.64 \\
Broj prijatelja & 879 & 0.20 & 4.00 & 2.96 & 0.70 & -1.01 & 1.15 \\
Vršnjačka prihvaćenost & 879 & 0.00 & 25.00 & 4.34 & 3.51 & 1.66 & 1.30 \\
Školski uspjeh & 879 & 1.00 & 3.00 & 2.64 & 0.48 & -1.27 & 1.01 \\
\hline & 876 & 1.17 & 5.00 & 3.75 & 0.89 & -0.37 & -0.74 \\
\hline
\end{tabular}

U Tablici 2. prikazana je učestalost uporabe različitih medija te socijalni kontekst $\mathrm{u}$ kojem adolescenti najčešće upotrebljavaju medije. Radi veće preglednosti varijablu učestalost uporabe različitih medija dihotomizirali smo tako da smo u prvu skupinu stavili odgovore koji se odnose na korištenje medija do pet sati dnevno/tjedno (1 - ne koristim, 2 - do 3 sata dnevno/tjedno i 3 - do 5 sati dnevno/tjedno), a u drugu skupinu više od pet sati dnevno/tjedno (4 - do 10 sati dnevno/tjedno, 5 - više od 10 sati dnevno/tjedno). Većina adolescenata gleda televiziju do pet sati dnevno (89.9\%) te igra računalne igrice $(69.2 \%)$ i koristi se internetom $(57 \%)$ do pet sati tjedno. Što se tiče socijalnog konteksta, televiziju najčešće gledaju u društvu roditelja (52.5\%), zatim s vršnjacima (31.3\%), a najmanje sami (16.2\%). Situacija je suprotna za računalne igrice i internet, koje upotrebljavaju 
najčešće sami (52.9\% računalne igrice, $59.3 \%$ internet), a na drugom mjestu u društvu vršnjaka (38.8\% računalne igrice, $27.7 \%$ internet).

Tablica 2. Učestalost uporabe različitih medija i socijalni kontekst

\begin{tabular}{lcccccccccc}
\hline & \multicolumn{4}{c}{ Učestalost uporabe } & \multicolumn{5}{c}{ Socijalni kontekst } \\
\cline { 2 - 11 } & Do 5 sati & $\begin{array}{c}\text { Više od 5 } \\
\text { sati }\end{array}$ & \multicolumn{2}{c}{ Sami } & Vršnjaci & \multicolumn{2}{c}{ Roditelji } \\
\cline { 2 - 11 } & $N$ & $\%$ & $N$ & $\%$ & $N$ & $\%$ & $N$ & $\%$ & $N$ & $\%$ \\
\hline $\begin{array}{l}\text { Televizija } \\
\text { (dnevno) }\end{array}$ & 785 & 89.9 & 88 & 10.1 & 141 & 16.2 & 273 & 31.3 & 456 & 52.5 \\
\hline $\begin{array}{l}\text { Računalne } \\
\text { igrice (tjedno) }\end{array}$ & 604 & 69.2 & 269 & 30.8 & 447 & 52.9 & 328 & 38.8 & 70 & 8.3 \\
\hline $\begin{array}{l}\text { Internet } \\
\text { (tjedno) }\end{array}$ & 497 & 57.0 & 376 & 43.0 & 511 & 59.3 & 239 & 27.7 & 112 & 13.0 \\
\hline
\end{tabular}

Dobiveni su rezultati u skladu s dosadašnjim istraživanjima u svijetu (Brug i sur., 2012; Verloigne i sur., 2015) i kod nas (AEM/UNICEF, 2014; Bilić, 2010; Hrabri telefon i Poliklinika za zaštitu djece grada Zagreba, 2008), što nam govori u prilogu o reprezentativnosti odabranog uzorka, odnosno daje nam dobru osnovnu za generalizaciju i provjeru pretpostavljenog problema.

Cilj je istraživanja bio provjeriti povezanost učestalosti korištenja različitih medija s nekim aspektima kognitivnog i socijalno-emocionalnog razvoja. U tu smo svrhu izračunali koeficijente korelacije (Tablica 3.) te koristeći Fisherov z-test razlika provjerili razlikuju li se jačine povezanosti ovisno o vrsti medija kojim se učenik koristi. Gotovi svi mjereni aspekti razvoja statistički su značajno povezani s učestalijim korištenjem medija (izuzev povezanosti vršnjačke prihvaćenosti $\mathrm{s}$ vremenom provedenim gledajući televiziju te školskog uspjeha s vremenom provedenim koristeći internet), iako su dobivene povezanosti relativno niske. Učestalije gledanje televizije povezano je s većim stupnjem impulzivnosti, nižom razinom afektivne empatije, većim brojem prijatelja i slabijim školskim uspjehom. Učestalije igranje računalnih igrica povezano je sa svim mjerenim aspektima razvoja, pri čemu je učestalije igranje računalnih igrica povezano s većim stupnjem impulzivnosti, nižom razinom afektivne empatije, većim brojem prijatelja, boljom vršnjačkom prihvaćenosti i slabijim školskim uspjehom, dok je učestalije korištenje interneta povezano s većim stupnjem impulzivnosti, nižom razinom afektivne empatije, većim brojem prijatelja i boljom vršnjačkom prihvaćenosti. Stupanj impulzivnosti jače se vezuje uz igranje računalnih igrica i uz korištenje interneta nego uz gledanje televizije, dok je stupanj afektivne empatije u tješnjoj vezi s igranjem računalnih igrica nego s korištenjem interneta. Osjećaj vršnjačke prihvaćenosti više je povezan s igranjem računalnih igrica i korištenjem interneta nego s gledanjem televizije dok je školski uspjeh u jačoj korelaciji s gledanjem televizije nego $s$ korištenjem interneta. Međutim, potrebno je naglasiti kako se radi se o malim 
razlikama u povezanostima i o malom broju ukupno dobivenih statistički značajnih razlika u korelacijama (Z-test).

Tablica 3. Povezanost učestalosti korištenja različitih vrsta medija s impulzivnosti, afektivnom empatijom, brojem prijatelja, osjećajem vršnjačke prihvaćenosti i školskim uspjehom

\begin{tabular}{lccccc}
\hline & Impulzivnost & $\begin{array}{c}\text { Afektivna } \\
\text { empatija }\end{array}$ & $\begin{array}{c}\text { Broj } \\
\text { prijatelja }\end{array}$ & $\begin{array}{c}\text { Vršnjačka } \\
\text { prihvaćenost }\end{array}$ & $\begin{array}{c}\text { Školski } \\
\text { uspjeh }\end{array}$ \\
\hline $\begin{array}{l}\text { Vrijeme provedeno gledajući } \\
\text { televiziju }\end{array}$ & $.09^{* *}$ & $-.17^{* * *}$ & $.14^{* * *}$ & -.02 & $-.15^{* * *}$ \\
$\begin{array}{l}\text { Vrijeme provedeno igrajući } \\
\text { računalne igrice }\end{array}$ & $.19^{* * *}$ & $-.23^{* * *}$ & $.17^{* * *}$ & $.10^{* *}$ & $-.07^{*}$ \\
$\begin{array}{l}\text { Vrijeme provedeno koristeći } \\
\text { internet }\end{array}$ & $.22^{* * *}$ & $-.13^{* * *}$ & $.10^{* *}$ & $.12^{* * *}$ & .01 \\
$\begin{array}{l}\text { Z-test (TV - igrice) } \\
\text { Z-test (TV - internet) }\end{array}$ & $2.05^{*}$ & -1.40 & -0.60 & $-2.33^{*}$ & 1.65 \\
Z-test (igrice - internet) & $-2.80^{* *}$ & 0.73 & 1.00 & $-2.75^{* *}$ & $3.23^{* *}$ \\
\hline
\end{tabular}
${ }^{*} p<.05 ;{ }^{* *} p<.01 ;{ }^{* * *} p<.001$.

U skladu s drugim dijelom problema napravili smo hijerarhijsku regresijsku analizu s dvije "dummy"-varijable koje predstavljaju socijalni kontekst. Prva se "dummy"-varijabla odnosi na to radi li se o socijalnom kontekstu roditelja ili su tijekom aktivnosti sami, dok se druga "dummy"-varijabla odnosi na socijalni kontekst prijatelja. Provjeravani su utjecaji socijalnog konteksta (sam, s roditeljima ili s prijateljima) na povezanost učestalosti tri različita medija (gledanje televizije, igranje računalnih igrica i korištenje interneta) s različitim aspektima razvoja. U svim regresijskim analizama kriteriji su bili isti, a odnose su se na različite aspekte razvoja djeteta: emocionalni (impulzivnost i afektivna empatija), socijalni (broj prijatelja i vršnjačka prihvaćenost) i kognitivni (školski uspjeh). Prediktori su se mijenjali ovisno o mediju kojim se učenik koristi (gledanje televizije, igranje računalnih igrica, korištenje interneta). U svim je primjerima provedena hijerarhijska regresijska analiza u dva koraka. U prvom su koraku uvedeni prediktori učestalosti korištenja određenog medija te socijalnog konteksta $u$ kojem se koristi medij, a u drugom su koraku dodani prediktori koji predstavljaju interakciju socijalnog konteksta i učestalosti korištenja određenog medija (koji mjere moderacijski efekt). 


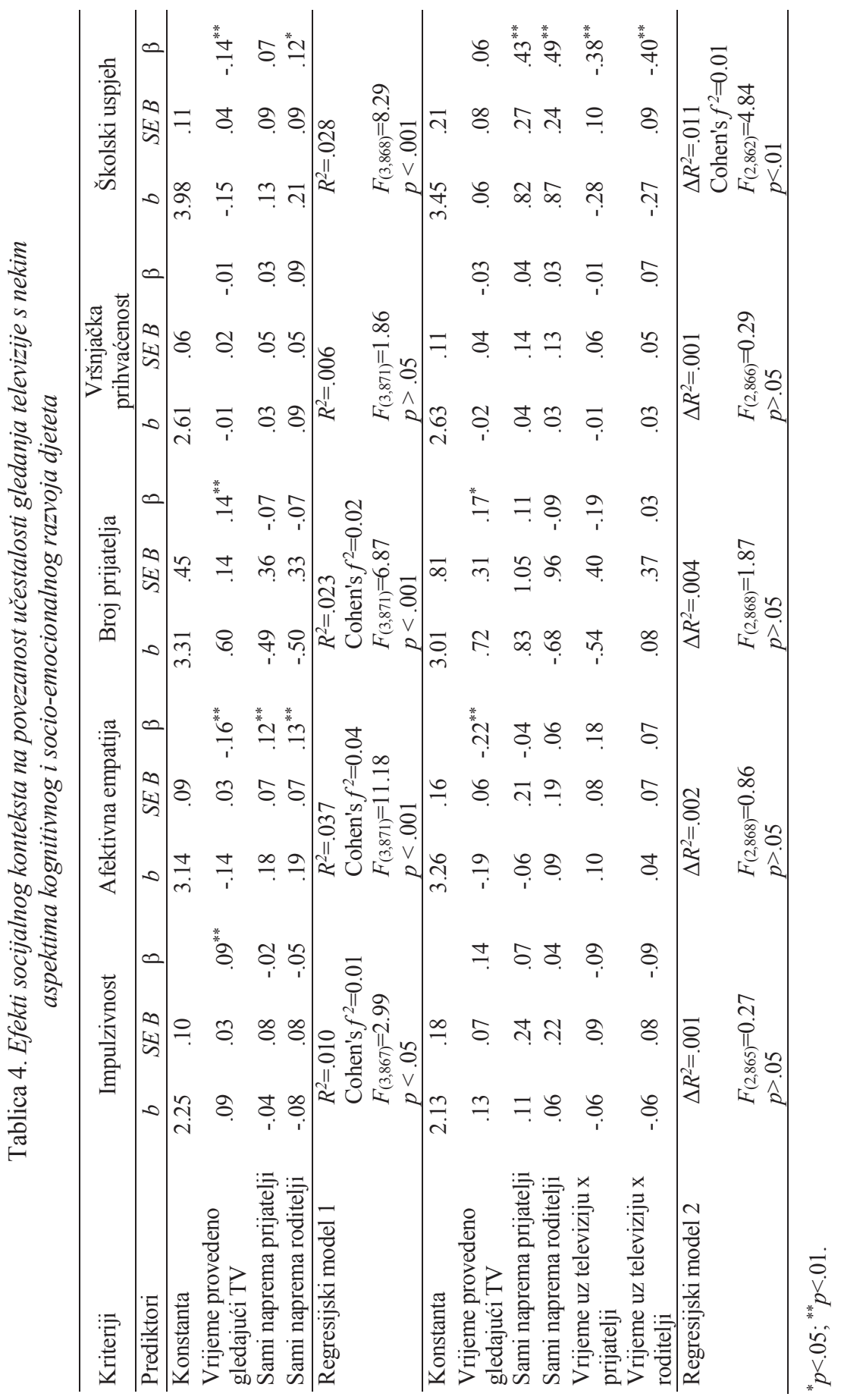


U Tablici 4. prikazani su rezultati za medij televizija. Dobiveni su jednostavni glavni efekti za impulzivnost $(\beta=.09, p<.01)$, afektivnu empatiju $(\beta=-.16, p<.01)$, broj prijatelja $(\beta=.14, p<.01)$. Više vremena provedenoga gledajući televiziju predviđa veći stupanj impulzivnosti, niži stupanj afektivne empatije i više prijatelja. Dobiveni su efekti između gledanja televizije u društvu prijatelja i afektivne empatije ( $\beta=-.12$, $p<.01)$ te gledanja televizije u društvu roditelja i afektivne empatije $(\beta=.13, p<.01)$. Međutim, dobiveni su efekti mali i izrazito mali (Cohen's $f^{2}=0.01-0.04$; Cohen, 1988, 1992).

Socijalni kontekst pokazao se moderatorom samo u nekim uvjetima. Za gledanje televizije socijalni kontekst pokazao se moderatorom efekata gledanja televizije na školski uspjeh. Dobiven je značajan, ali izrazito mali interakcijski efekt ( $\beta=.38-.40, p<0.01$, Cohen's $f^{2}=0.01$; Cohen, 1988, 1992). Također, u obzir treba uzeti kako moderacijski efekti objašnjavaju svega dodatnih $1 \%$ ukupne varijance $\left(\Delta R^{2}=.011\right)$ u odnosu na Model 1.

Slika 1. Prikaz moderacijskog efekta oba socijalna konteksta (roditeljska i vršnjačka prisutnost) na povezanost vremena provedenog gledajući televiziju s prosjekom ocjena

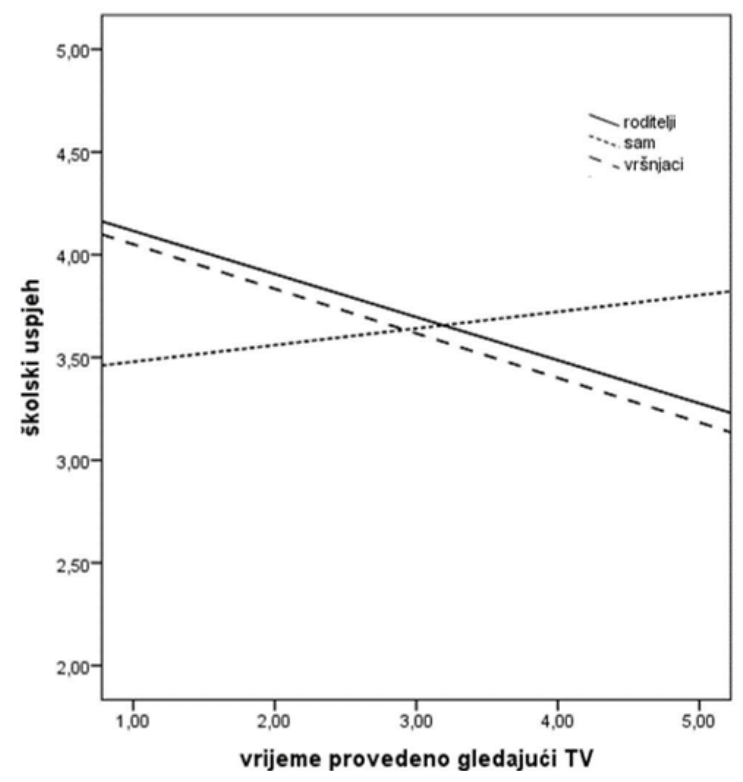

Moderacijski efekt socijalnog konteksta roditelja i vršnjaka djeluje na smjer odnosa između vremena provedenog gledajući televiziju i školskog uspjeha, pri čemu više vremena provedenog uz televiziju znači i bolji školskih uspjeh ako djeca sama gledaju televiziju. Međutim, kada gledaju televiziju s roditeljima ili vršnjacima, više sati provedenih gledajući televiziju u društvu roditelja ili vršnjaka znači i slabiji školski uspjeh. 


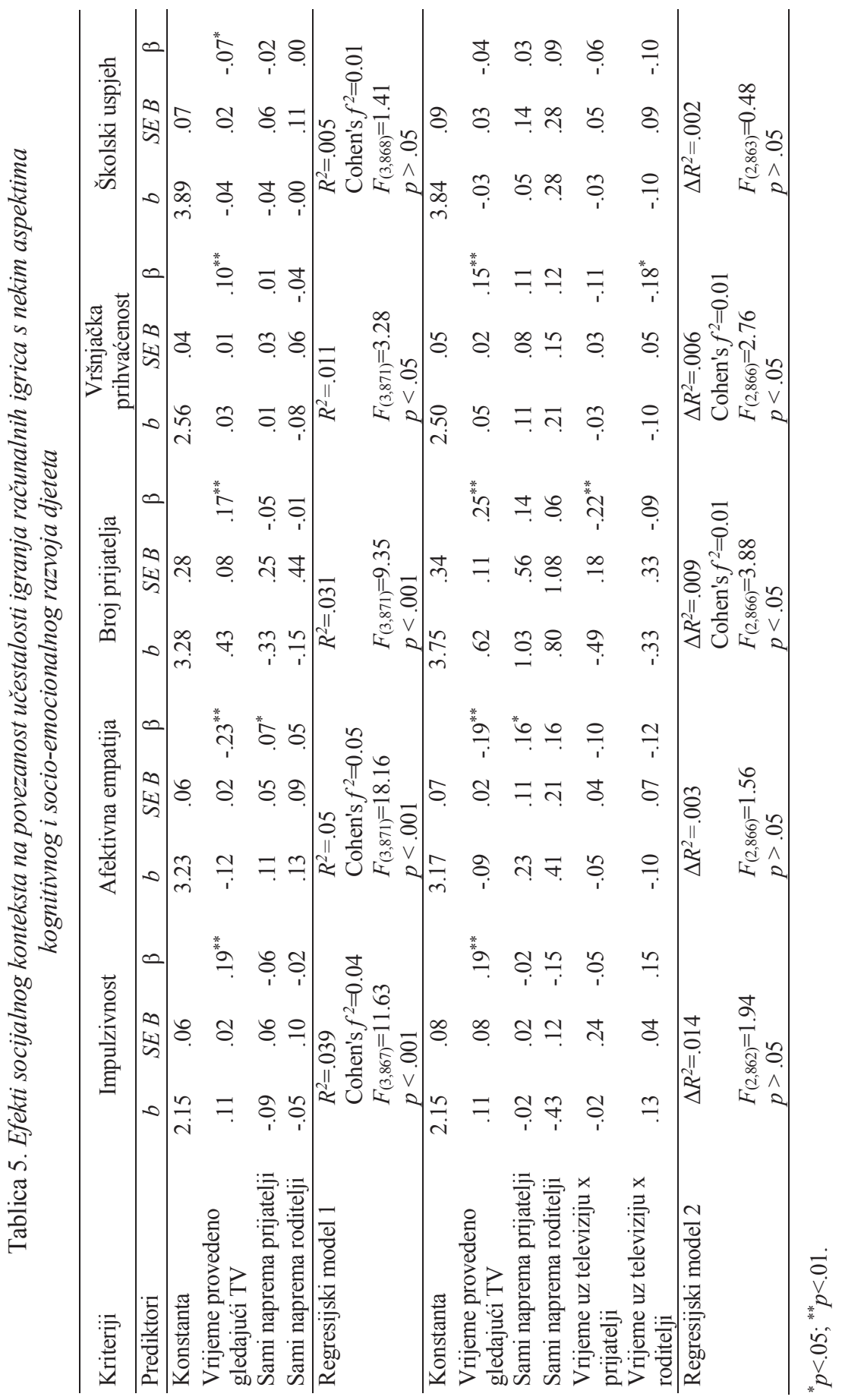


U Tablici 5. prikazani su rezultati za medij računalne igrice. Jednostavni glavni efekti dobiveni su za sve mjerene aspekte razvoja. Više vremena provedenog igrajući računalne igrice predviđa veći stupanj impulzivnosti $(\beta=.19, p<.01)$, niži stupanj afektivne empatije $(\beta=-.23, p<.01)$ te slabiji školski uspjeh $(\beta=-.07, p<.05)$. Dobiven je i efekt između igranja računalnih igrica u društvu prijatelja i stupnja afektivne empatije $(\beta=.07, p<.05)$. Svi dobiveni efekti kreću se od izrazito malih do malih (Cohen's $f^{2}=0.01-0.05$; Cohen, 1988, 1992).

Dobivena su i dva moderacijska efekta socijalnog konteksta koji su izrazito mali (Cohen's $f^{2}=0.01$; Cohen, 1988, 1992): socijalni kontekst prijatelja pokazao se moderatorom odnosa između vremena provedenog igrajući računalne igrice i broja prijatelja $(\beta=-.22, p<.01)$ te socijalni kontekst roditelja između vremena provedenog igrajući računalne igrice $\mathrm{i}$ vršnjačke prihvaćenosti $(\beta=-.18, p<.05)$. Moderacijski efekt socijalnog konteksta vršnjaka i roditelja nema gotovo nikakav stvarni efekt. Model s uključenim značajnim interakcijama dodatno objašnjava manje od $1 \%$ $\left(\Delta R^{2}=.009\right)$ ukupne varijance za socijalni kontekst vršnjaka, a za socijalni kontekst roditelja samo dodatnih $0.6 \%\left(\Delta R^{2}=.006\right)$ ukupne varijance.

Slika 2. Prikaz moderacijskog efekta vršnjačke prisutnosti na povezanost vremena provedenog igrajući računalne igrice s brojem najboljih prijatelja

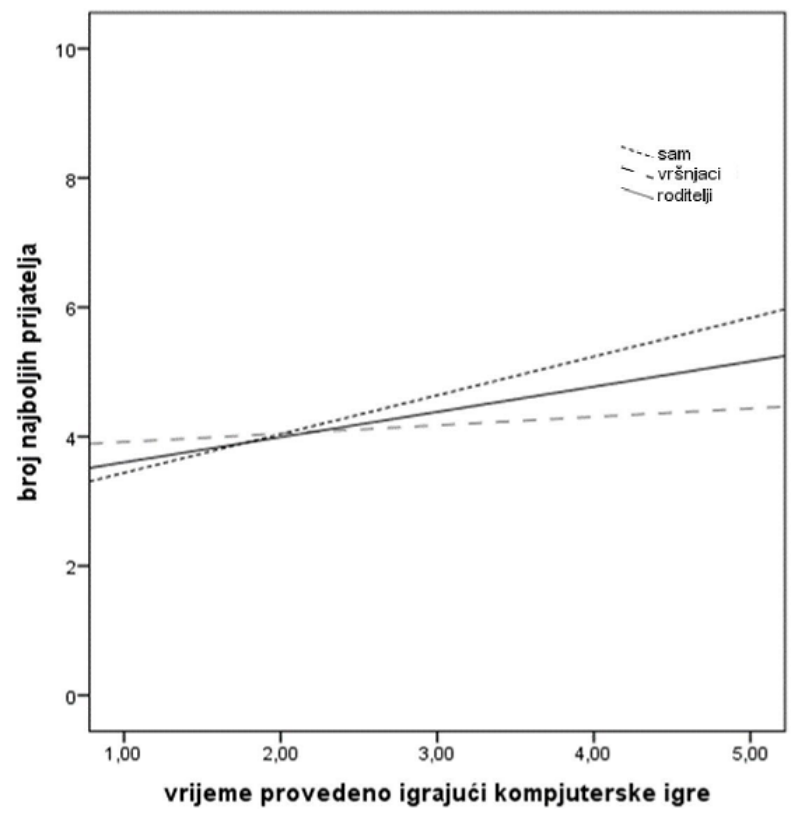

Interakcijski efekt, odnosno moderacija socijalnog konteksta, dobivena je za odnos količine vremena provedenog igrajući računalne igrice i broja najboljih prijatelja, pri čemu djeca imaju manji broj prijatelja kada se igraju sami nego kada se igraju u društvu vršnjaka. 
Slika 3. Prikaz moderacijskog efekta roditeljske prisutnosti na povezanost vremena provedenog igrajući računalne igrice s osjećajem vršnjačke pripadnosti

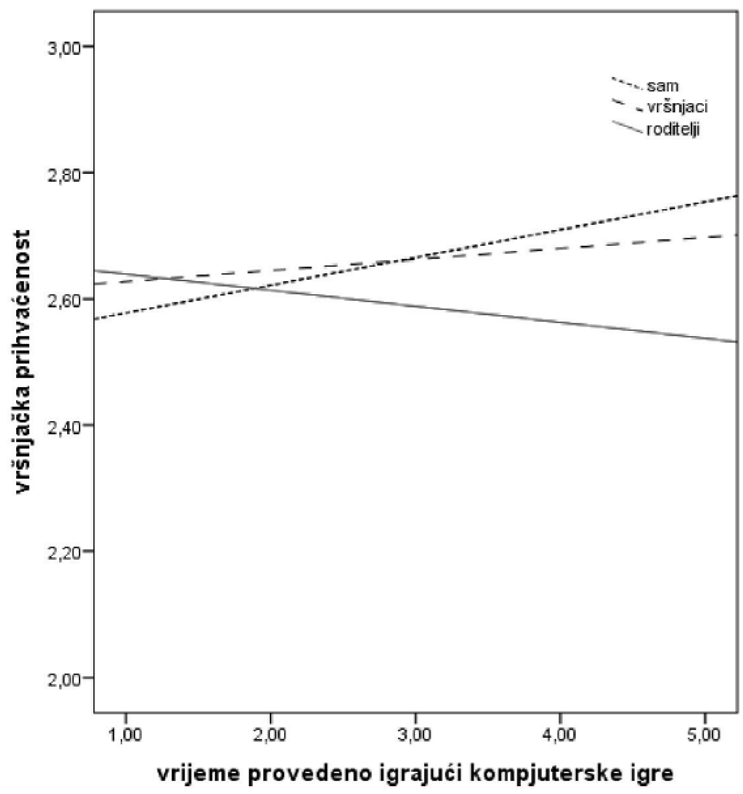

Smjer odnosa između vremena provedenog u igranju računalnih igrica i osjećaja vršnjačke prihvaćenosti moderira socijalni kontekst roditelja, pri čemu više vremena provedenog u igranju računalnih igrica u društvu roditelja znači slabiju vršnjačku prihvaćenost nego u slučaju kada se igraju sami. Pri tome više vremena provedenog u igranju računalnih igrica znači i bolju vršnjačku prihvaćenost.

U Tablici 6. prikazani su rezultati za medij internet. Jednostavni glavni efekti vremena provedenog koristeći internet dobiveni su za impulzivnost $(\beta=.22, p<.01)$, afektivnu empatiju ( $\beta=-.13, p<.01)$, broj prijatelja $(\beta=.09, p<.01)$ i vršnjačku prihvaćenost $(\beta=.11, p<.01)$. Više vremena provedenog koristeći internet predviđa veći stupanj impulzivnosti, niži stupanj afektivne empatije, više prijatelja te bolju vršnjačku prihvaćenost. Dobiveni su efekti mali i izrazito mali (Cohen's $f^{2}=0.01$ 0.05; Cohen, 1988, 1992). Socijalni kontekst nema značajnu ulogu kod korištenja interneta. 


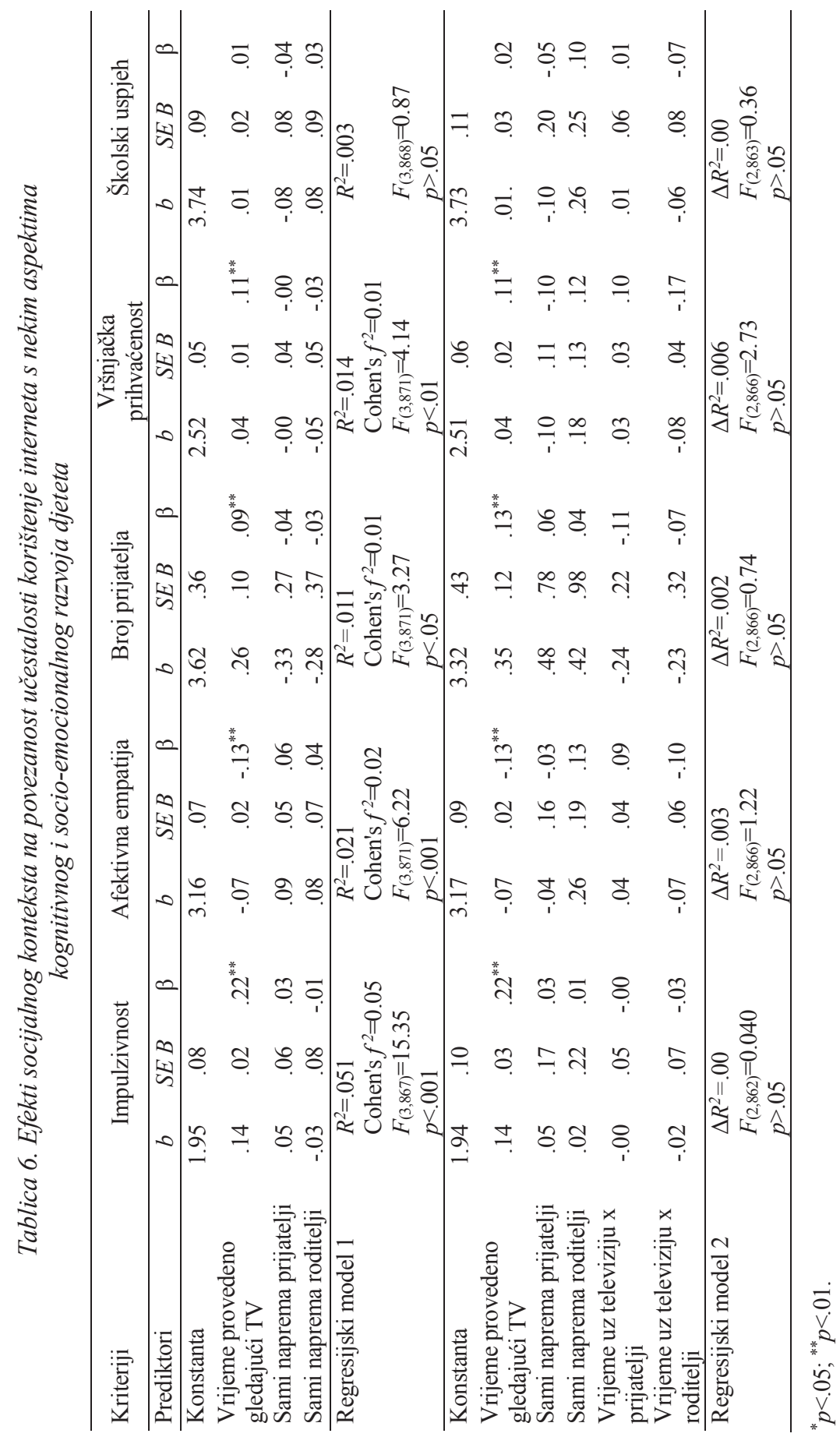




\section{Rasprava}

Način mišljenja djece i mladih pod velikim je utjecajem medija, koji oblikuju kulturu i norme društva, sve do pojedinog dijela ekološkog sustava pa tako i do mikrorazine, kao što su obitelj i škola (Bronfenbrenner, 2005). Na temelju dobivenih rezultata postoji značajna povezanost između učestalosti korištenja medija i gotovo svih ispitivanih aspekata razvoja te su dobivene i značajne razlike u korelacijama ovisno o mediju kojim se dijete koristi, no treba naglasiti da se radi o malim razlikama u dobivenim povezanostima.

Što se tiče socijalnog konteksta, učenici navode kako najčešće sami upotrebljavaju internet (59.3\%) i sami igraju igrice (52.9\%), a televiziju gledaju s roditeljima $(52.5 \%)$ (Tablica 2.). U hrvatskom istraživanju navika korištenja interneta učenici viših razreda osnovnih škola (Šincek, Tomašić Humer i Duvnjak, 2015) internetom se u prosjeku koriste gotovo tri sata dnevno. S obzirom na to da kultura, odnosno zemlja porijekla djeteta može imati značajan utjecaj na korištenje medija (Verloigne i sur., 2015), provjerili smo moderacijski efekt socijalnog konteksta za našu kulturu. Dobiven je vrlo slab moderacijski efekt za sve socijalne kontekste u određenim uvjetima.

Za medij televizija dobivena je statistički značajna povezanost s impulzivnosti, afektivnom empatijom, brojem prijatelja i školskim uspjehom, pri čemu učenici koji više vremena gledaju televiziju imaju i veći stupanj impulzivnosti, niži stupanj afektivne empatije, više prijatelja i slabiji školski uspjeh. Najviše se ističe socijalni kontekst u kojem učenici gledaju televiziju s vršnjacima ili roditeljima, no dobiveni je efekt mali. Gledanje televizije u društvu prijatelja ili roditelja predviđa viši stupanj afektivne empatije. Što se tiče školskog uspjeha, on je niži ako gledaju televiziju u prisustvu roditelja ili vršnjaka, a viši ako sami gledaju televiziju. Dobiven je izrazito mali moderacijski efekt socijalnog konteksta roditelja i vršnjaka na gledanje televizije i školski uspjeh, a značajni prediktori objašnjavaju izrazito mali postotak varijance rezultata. Djeca i adolescenti gledanje televizije češće koriste radi zabave i opuštanja, što nerijetko može negativno utjecati na školski uspjeh (Schmidt i Vandewater, 2008), stoga ne čudi da gledanje televizije u društvu prijatelja ili roditelja može biti povezano sa slabijim školskim uspjehom. S druge strane, učenici u najmanjoj mjeri gledaju televiziju sami (16.2\%, Tablica 2.), a od njih $85.6 \%$ gleda manje od pet sati dnevno, pa ne dovodi do negativnih posljedica. Roditelji koji su zabrinutiji za negativne posljedice gledanja televizije i oni uvjereni u pozitivne učinke češće gledaju zajedno i/ili razgovaraju te procjenjuju sadržaje medija sa svojom djecom (Nikken i Jansz, 2004). Gledanje televizije navodi se kao najčešća zajednička aktivnost roditelja i djeteta (Nikken i Jansz, 2004) pri čemu je bitno da roditelji vrše aktivni nadzor (uz komentiranje i/ili odabir sadržaja), iako i samo prisustvo roditelja djeluje u smjeru da će djeca pažljivije birati sadržaj koji gledaju, odnosno skloniji su poštovati društvene norme i u skladu s njima odabirati programe koji su prikladniji njihovu uzrastu (Nathanson, 2001). Preko 30\% djece gleda 
televiziju u društvu roditelja ili vršnjaka više od pet sati dnevno čime se može objasniti dobivena negativna povezanost. Međutim, dobiveni rezultati pokazuju kako su moderacijski efekti socijalnog konteksta za gledanje televizije izrazito mali, što dovodi u pitanje ima li uopće socijalni kontekst u kojem djeca gledaju televiziju utjecaj na razvoj djeteta.

Svi mjereni aspekti razvoja značajno su povezani s vremenom provedenim igrajući računalne igrice, pri čemu učenici koji više vremena provedu igrajući računalne igrice imaju veći stupanj impulzivnosti, niži stupanj afektivne empatije, više prijatelja, bolju vršnjačku prihvaćenost te slabiji školski uspjeh. Za igranje računalnih igrica značajnim se pokazao socijalni kontekst vršnjaka čiji je efekt mali, pri čemu učenici iskazuju višu razinu afektivne empatije ako se igraju s vršnjacima. Računalne igrice nisu djeci važne samo kada ih igraju sami nego i u društvu prijatelja. Dječaci češće igraju igrice s prijateljima nego djevojčice i igrice su sastavni dio njihovih vršnjačkih aktivnosti (Fromme, 2003). U takvim se situacijama mogu uspoređivati i natjecati jedni s drugima, pokazivati napredak u igrici, pomoći drugima ili ih savjetovati te raspravljati o igricama. Stoga, vršnjaci mogu emocionalno i motivacijski osnažiti pojedinca (Robertson i Howells, 2008). Nadalje, dobiven je izrazito mali moderacijski efekt socijalnog konteksta vršnjaka koji djeluje na odnos između vremena provedenog u igranju računalnih igrica i broja prijatelja, pri čemu učenici imaju veći broj prijatelja ako se igraju sami. Moguće je objašnjenje da učenici tijekom igranja igrica imaju više mogućnosti i prilika steći nove prijatelje, dok kada se igraju s vršnjacima, igra se usmjerava na postojeće prijatelje. No, radi se o izrazito slabom moderacijskom efektu te ovaj medij objašnjava minimalan postotak varijance rezultata što upućuje na to da socijalni kontekst ne mora biti važan aspekt razvoja, kako je pretpostavljeno.

Slično je dobiveno i za moderacijski efekt konteksta roditelja pri igranju računalnih igrica koji dovodi do slabije vršnjačke prihvaćenosti, što se može objasniti time da roditeljska prisutnost ne dopušta djeci komunikaciju i slobodu kakvu bi inače iskazivali tijekom igranja igrica kada su sami, a također je moguće i da su zbog usmjerenosti na roditelje manje skloni uspostavljanju vršnjačkih odnosa. Jednako kao i kod prethodnog moderacijskog efekta, model opisuje mali postotak varijance i ima izrazito mali efekt. Prisutnost roditelja i vršnjaka kao moderator varijabla je koja može promijeniti smjer ili jačinu efekta korištenja medija na mjerene ishode (Valkenburg i Peter, 2013), ali očito u provedenom istraživanju ima izrazito slab efekt te je upitno djeluje li uistinu kao moderator.

Dobivena je značajna povezanost između vremena provedenog koristeći internet i impulzivnosti, afektivne empatije, broja prijatelja i vršnjačke prihvaćenosti. Učenici koji više vremena provode koristeći internet imaju veći stupanj impulzivnosti, niži stupanj afektivne empatije, više prijatelja te bolju vršnjačku prihvaćenost. Povezanost impulzivnosti i korištenja interneta može se promatrati na način da impulzivnost može biti jedan od važnih faktora za ovisnost o internetu, no moguće je i obratno (Yoo i sur., 2004). Za povezanost s empatijom potvrđeni su 
nalazi kao i u sličnim istraživanjima; na primjer Engelberg i Sjöberg (2004) navode kako učenici koji se često koriste internetom imaju nižu razinu emocionalne kompetencije. Nadalje, na njemačkom i kineskom uzorku adolescenata dobiveno je kako je niža razina empatije povezana s prekomjernim korištenjem interneta (Melchers, Li, Chen, Zhang i Montag, 2015). Što se tiče prihvaćenosti i broja prijatelja, neki autori (Bargh i McKenna, 2004) navode kako korištenje interneta može biti negativno povezano s problemima prilagodbe, pri čemu se socijalno kompetentne osobe jednako ponašaju prema okruženju na internetu kao i prema bilo kojem drugom okruženju u kojem ostvaruju interakciju s prijateljima i proširuju socijalnu mrežu. Međutim, socijalni kontekst nije se pokazao značajnim za korištenje interneta.

Učestalije igranje računalnih igrica povezano je sa svim mjerenim aspektima razvoja. Međutim, stupanj impulzivnosti nešto je izraženije povezan uz igranje računalnih igrica i korištenje interneta nego uz gledanje televizije. Vrijeme provedeno u igranju igrica zamjenjuje vrijeme koje bi djeca provela u nekim drugim aktivnostima koje bi omogućile razvoj veće kontrole impulsa. Uporaba elektroničkih medija može smanjiti sposobnost samokontrole (Gentile, Swing, Lim i Khoo, 2012). Igranje igrica je vrlo uzbudljivo i zabavno te uključuje snažne znakove koji privlače pozornost i značajke koje aktiviraju usmjeravajuću reakciju, kao što su zvučni efekti, titraji razine svjetla i slično (Kubey i Csikszentmihalyi, 2002). Za vrijeme igranja računalnih igrica, kao i za vrijeme korištenja interneta, potrebna je veća uključenost djeteta u aktivnost, za razliku od pasivnog gledanja televizije, tako da ne čudi da ovi mediji, kao izrazito dinamični sustavi, pokazuju jaču povezanost s impulzivnosti. Sadržaj igrica može utjecati na teškoće pozornosti i impulzivnost, no važnije je ukupno vrijeme koje djeca provode igrajući igrice. Što više vremena provode igrajući računalne igrice, iskazuju impulzivnija ponašanja i lakše prihvaćaju nasilje (Rehbein i Baier, 2013). Nagrađivanje nasilnih postupaka u računalnim igricama povećava vjerojatnost nasilnog i impulzivnog ponašanja (Grüsser, Thalemann i Griffiths, 2007).

$\mathrm{Za}$ stupanj afektivne empatije dobivena je statistički značajna negativna povezanost $\mathrm{s}$ vremenom provedenim koristeći svaki uključeni medij u istraživanje. Međutim, pokazalo se kako je stupanj afektivne empatije nešto izraženije negativno povezan uz igranje računalnih igrica nego korištenje interneta $i$ da do porasta afektivne empatije dolazi ako učenici gledaju televiziju s vršnjacima ili roditeljima. Igranje računalnih igrica zahtijeva veću uživljenost u kontekst i sadržaj. U većini računalnih igrica može se pronaći poprilično visoka razina nasilja (Gentile, Lynch, Linder i Walsh, 2004), a igranjem takvih igrica povećava se razina tolerancije na nasilje i smanjuje empatija jer se potiče i nagrađuje nasilje (Krahé i Möller, 2010). Stoga ne čudi da upravo ovaj mediji ima najsnažniju negativnu povezanost sa stupnjem afektivne empatije. Funk, Baldacci, Pasold i Baumgardner (2004) su pronašli negativnu povezanost između igranja nasilnih računalnih igrica i empatije djece osnovnoškolske dobi. 
Broj prijatelja značajno je povezan s vremenom provedenim koristeći svaki medij, no ne postoji značajna razlika u korelacijama. Učenici mogu različite medije koristiti zajedno s prijateljima i novim vršnjacima te i kroz samo korištenje stjecati nove prijatelje.

Za osjećaj vršnjačke prihvaćenosti postoji razlika u korelacijama te je on tješnje povezan $\mathrm{s}$ igranjem računalnih igrica $\mathrm{i}$ korištenjem interneta nego $\mathrm{s}$ gledanjem televizije, što je i očekivano. Rezultati pokazuju kako gotovo $40 \%$ učenika (Tablica 2.) provodi vrijeme s prijateljima u igranju računalnih igrica. Poznato je kako postoji puno grupnih računalnih igrica koje se igraju na internetu (npr. na Facebooku) u dogovoru s prijateljima te se na takav način ujedno i druže. Stoga nije iznenađujuće kako se ispitani učenici osjećaju prihvaćeno od strane vršnjaka. Shaw i Gant (2002) su uočili da se s povećanjem korištenja ovakvih sredstava znatno smanjio osjećaj usamljenosti, ali i da je došlo do povećanja osjećaja samopoštovanja.

Istraživanja utjecaja medija pokazuju umjerenu negativnu povezanost između vremena koje djeca provode gledajući televiziju i njihova školskog uspjeha (Mößle, Kleimann, Rehbein i Pfeiffer, 2010; Schmidt i Vandewater, 2008). Češće gledanje televizije, više od jedanaest sati tjedno, negativno je povezano sa školskim uspjehom (Potter, 1987; prema Schmidt i Vandewater, 2008), što je u skladu s dobivenim rezultatima u provedenom istraživanju (3-5 sati dnevno, odnosno više od 21 sat tjedno, $M=2.42$ sata dnevno, Tablica 1.). Postoje nalazi koji govore i o dugotrajnom štetnom utjecaju gledanja televizije u djetinjstvu i adolescenciji koje je povezano $s$ akademskim uspjehom u kasnijoj dobi (Hancox, Milne i Poulton, 2005). Koristi od gledanja televizije pokazale su se povezanima s određenim obrazovnim programima više nego s ukupnim vremenom gledanja (Anderson, Huston, Schmitt, Linebarger i Wright, 2001). Što se tiče školskog uspjeha i korištenja interneta, suprotno dobivenim nalazima ovog istraživanja, Jackson, Biocca, von Eye, Barbatsis, Zhao i Fitzgerald (2004) pokazali su kako su učenici koji su se češće koristili internetom imali i više prosječne ocjene te su postizali više rezultate na testovima čitanja. Jedno je od mogućih objašnjenja da učenici dok upotrebljavaju internet češće to rade $u$ edukativne svrhe (npr. kao pomoć oko pisanja lektire, zadaća ili traženje informacija koje ih zanimaju) što uključuje razvijanje vještina čitanja. Kod igranja računalnih igrica, Durkin i Barber (2002) također su potvrdili da učenici koji u manjoj mjeri igraju igrice imaju više ocjene od onih koji vrlo često igraju igrice (svakodnevno).

Možemo zaključiti kako je u provedenom istraživanju upitno u kojoj mjeri roditelji i prijatelji predstavljaju moderatore, iako su učenici vjerojatno više svjesni društvenih pravila $i$ normi te ih više poštuju u njihovu prisustvu. No unatoč pretpostavkama kako socijalni kontekst ima važnu ulogu u djetetovu razvoju, nismo potvrdili trend kako prisustvo roditelja i vršnjaka utječe na socijalno-emocionalni i kognitivni razvoj, što se može pripisati promjenama u načinima korištenja medija te promjenama u roditeljskom nadzoru. Nadalje, vrlo je važno i koji sadržaj dijete prima medijem, odnosno kakva je njegova poruka i ima li socijalni kontekst aktivnu ulogu u korekciji poruka iz medija, što je potrebno detaljno istražiti. 
Dobiveni rezultati nisu u potpunosti očekivani jer smo očekivali kako će roditeljska prisutnost imati jači utjecaj na povezanost korištenja medija i dječjeg razvoja, ali su u skladu s većinom prijašnjih istraživanjima. Moguća obrazloženja pronalazimo u ograničenjima provedenog istraživanja. Prvo, za sve su mjere korišstene samoprocjene. Preporučuje se da buduća istraživanja upotrebljavaju različite objektivnije indekse prihvaćenosti unutar grupe dobivene na temelju vršnjačke procjene koji bi dali bolji uvid u socijalni aspekt razvoja. Također, varijablu roditeljska prisutnost trebalo bi jasnije operacionalizirati (npr. što roditelj govori ili komentira za vrijeme gledanja televizije ili dok se dijete koristi internetom) te u obzir uzeti roditeljske procjene. Nadalje, za mjeru kognitivnog aspekta razvoja koristili smo varijablu školski uspjeh (sastavljena prema strožem kriteriju; Vrdoljak i Velki, 2012), koja obuhvaća samo manji dio kognitivnog razvoja. Preporuča se da se u budućim istraživanjima svakako rabe dodatne mjere, npr. različiti testovi inteligencije. Dodatno, u istraživanju smo zahvatili samo afektivni aspekt empatije, a mediji mogu imati puno širi utjecaj na različite aspekte emocionalnog razvoja. Stoga se preporučuje da buduća istraživanja svakako obuhvate i druge aspekte emocionalnog razvoja, posebice emocionalnu inteligenciju. Što se tiče učestalosti korištenja medija, bilo bi poželjno uzeti u obzir i različite aspekte korištenja medija (na primjer, sadržaje koje učenici gledaju/pretražuju na internetu). Nadalje, iako značajni prediktori dječjeg razvoja, sva su tri medija objasnila mali postotak varijance zavisnih varijabli (1\%-6\%) različitih aspekata razvoja i imaju izrazito mali efekt, što nas navodi na zaključak da postoje puno važniji čimbenici koji imaju snažniji efekt na dječji razvoj nego što su to sami mediji. Svakako pri budućim istraživanjima treba simultano $\mathrm{s}$ efektom medija ispitati i druge čimbenike koji predviđaju dječji razvoj kako bismo opravdano mogli raspravljati o samoj ulozi i doprinosu medija na neke aspekte dječjeg razvoja.

\section{Zaključak}

Općenito gledajući potvrdili smo opći trend prijašnjih istraživanja koji govori u prilog činjenici da česta upotreba medija ima negativan efekt na socijalnoemocionalni razvoj djece. Međutim, dobiveni rezultati pokazuju izrazito slab efekt samih medija na različite aspekte razvoja, čak i kada u obzir uzmemo različite socijalne kontekste u kojima djeca koriste medije. Očito je da sama količina korištenje medija nije ključan čimbenik koji djeluje na razvoj djeteta. Nadalje, suprotno očekivanjima, prisutnost roditelja imala je tek slab moderacijski efekt, stoga možemo zaključiti da roditelji nisu uvijek ključan čimbenik u smanjivanju negativnog efekta medija te da u obzir treba uzeti i neke druge čimbenike i procese koji bi mogli imati važnu ulogu u sprječavanju negativnog efekta medija na razvoj djece. 


\section{Literatura}

Acevedo-Polakovich, I.D., Lorch, E.P. i Milich, R. (2007). Comparing television use and reading with ADHD and non-referred children across two age groups. Media Psychology, 9, 447-472. doi:10.1080/15213260701291387

AEM/UNICEF CROATIA (2014). Kako djeca gledaju TV program? IPSOS Media CT. Preuzeto s http://www.unicef.hr/sto-radimo/istrazivanja/

Anderson, D.R. i Collins, P.A. (1988). The influence on children's education: The effects of television on cognitive development. Washington, D.C.: U.S. Department of Education.

Anderson, D.R., Huston, A.C., Schmitt, K.L., Linebarger, D.L. i Wright, J.C. (2001). Early childhood television viewing and adolescent behavior: The recontact study. Monographs of the Society for Research in Child Development, 66(1), 1-154. doi:10.1111/1540-5834.00120

Bargh, J.A. i McKenna, K.Y. (2004). The Internet and social life. Annual Review of Psychology, 55, 573-590. doi:10.1146/annurev.psych.55.090902.141922

Bilić, V. (2010). The relation between media violence and aggressive peer behaviour. Odgojne znanosti, 12(20), 263-281.

Bronfenbrenner, U. (1979). The ecology of human development. Cambridge, MA: Harvard University Press.

Bronfenbrenner, U. (2005). Making human beings human. CA: Thousand Oaks.

Brug, J., van Stralen, M.M., Te Velde, S.J., Chinapaw, M.J., De Bourdeaudhuij, I., Lien, N., ... Manios, Y. (2012). Differences in weight status and energy-balance related behaviors among school children across Europe: The ENERGY-project. PloS one, 7(4). doi:10.1371/ journal.pone.0034742

Burgess, S.R., Stermer, S. i Burgess, M.R. (2012). Video game playing and academic performance in college students. College Student Journal, 46(2), 376-387. doi:10.1111/ j.2150-1092.2012.00045_34.x

Bushman, B.J. i Huesmann, L.R. (2006). Short-term and long-term effects of violent media on aggression in children and adults. Archives of Pediatrics and Adolescent Medicine, 160(4), 348-352. doi:10.1016/j.jadohealth.2007.09.005

Chan, P.A. i Rabinowitz, T. (2006). A cross-sectional analysis of video games and attention deficit hyperactivity disorder symptoms in adolescents. Annals of General Psychiatry, 5(16). doi:10.1186/1744-859X-5-16

Cohen, J. (1988). Statistical power analysis for the behavioral sciences. New Jersey: Lawrence Erlbaum Associates, Inc. Publishers.

Cohen, J. (1992). A power primer. Psychological Bulletin, 112(1), 155-159.

Drummond A. i Sauer J.D. (2014). Video-games do not negatively impact adolescent academic performance in science, mathematics or reading. Plos One, 9(4), 1-5. doi:10.1371/journal.pone.0087943

Durkin, K. i Barber, B. (2002). Not so doomed: Computer game play and positive adolescent development. Applied Developmental Psychology, 23(4), 373-392. doi:10.1016/ S01933973(02)00124-7 
Engelberg, E. i Sjöberg, L. (2004). Internet use, social skills, and adjustment. CyberPsychology \& Behavior, 7(1), 41-47. doi:10.1089/109493104322820101

Fromme, J. (2003). Computer games as a part of children's culture. The International Journal of Computer Game Research, 3(1). Preuzeto s http://www.gamestudies.org/0301/ fromme/

Funk, J.B. (2005). Children's exposure to violent video games and desensitization to violence. Child and Adolescent Psychiatric Clinics of North America, 14, 387-404. doi:http://dx.doi.org/10.1016/j.chc.2005.02.009

Funk, J.B., Baldacci, H.B., Pasold, T. i Baumgardner, J. (2004). Violence exposure in reallife, video games, television, movies, and the internet: Is there desensitization? Journal of Adolescence, 27, 23-39. doi:10.1016/j.adolescence.2003.10.005

Gentile, D.A., Groves, C.L. i Gentile, J. (2014). The general learning model: Unveiling the teaching potential of video games. U: F.C. Blumberg (Ur.), Learning by playing: Video gaming in education (str. 121-142). New York, NY: Oxford University Press.

Gentile, D.A., Lynch, P.J., Linder, J.R. i Walsh, D.A. (2004). The effects of violent video game habits on adolescent hostility, aggressive behaviors, and school performance. Journal of Adolescence, 27, 5-22. doi:10.1016/j.adolescence.2003.10.002

Gentile, D.A., Swing, E.L., Lim, C.G. i Khoo, A. (2012). Video game playing, attention problems, and impulsiveness: Evidence of bidirectional causality. Psychology of Popular Media Culture, 1(1), 62-70. doi:10.1037/a0026969

Grüsser, S.M., Thalemann, R. i Griffiths, M.D. (2007). Excessive computer game playing: Evidence for addiction and aggression? CyberPsychology \& Behavior, 10(2), 290-292. doi:10.1089/cpb.2006.9956

Hancox, R.J., Milne, B.J. i Poulton, R. (2005). Association of television viewing during childhood with poor educational achievement. Archives of Pediatrics and Adolescent Medicine, 159(7), 614-618. doi:10.1001/archpedi.159.7.614

Houghton, S., Milner, N., West, J., Douglas, G., Lawrence, V., Whiting, K., Tannock, R. i Durkin, K. (2004). Motor control and sequencing of boys with attention deficit/hyperactivity disorder during computer game play. British Journal of Educational Technology, 35(1), 21-34. doi:10.1111/j.1467-8535.2004.00365.x

Hrabri telefon i Poliklinika za zaštitu djece grada Zagreba (2008). Nasilje preko interneta cyberbullying. Preuzeto s http://www.poliklinika-djeca.hr/publikacije/nasilje-prekointerneta/

Ilišin, V. (2003). Mediji u slobodnom vremenu djece i komunikacija o medijskim sadržajima. Medijska istraživanja, 9(2), 9-34.

Ivanović, M. i Buško, V. (2008). Razvoj upitnika empatije. Neobjavljen rad.

Jackson, L., Biocca, F., von Eye, A., Barbatsis, G., Zhao, Y. i Fitzgerald, H. (2004). Children's internet use: Findings from the HomeNetToo Project. U: L. Cantoni i C. McLoughlin (Ur.), Proceedings of EdMedia: World conference on educational media and technology 2004 (str. 4763-4769). Lugano, Switzerland: Association for the Advancement of Computing in Education (AACE). 
Jordan, A. (2004). The role of media in children's development: An ecological perspective. Journal of Developmental and Behavioral Pediatrics, 25, 196-206. doi:10.1097/ 00004703-200406000-00009

Klapper, J.T. (1960). The effects of mass communication. New York, NY: Free Press.

Krahé, B. i Möller, I. (2010). Longitudinal effects of media violence on aggression and empathy among German adolescents. Journal of Applied Developmental Psychology, 31, 401-409. doi:10.1016/j.appdev.2010.07.003

Kraut, R., Patterson, M., Lundmark, V., Kiesler, S., Mukopadhyay, T. i Scherlis, W. (1998). Internet paradox: A social technology that reduces social involvement and psychological well-being? American Psychologist, 53(9), 1017-1031. doi:10.1037/0003-066X.53.9. 1017

Krcmar, M. (2009). Individual differences in media effects. U: R.L. Nabi i M.B. Oliver (Ur.), The Sage handbook of media processes and effects (str. 237-250). Los Angeles, CA: Sage.

Kubey R. i Csikszentmihalyi, M. (2002). Television addiction is no mere metaphor. Scientific American, 286, 74-80.

Lenhart, A., Kahne, J., Middaugh, E., Rankin Macgill, A., Evans, C. i Vitak, J. (2008). Teens, video games, and civics: Teens' gaming experiences are diverse and include significant social interaction and civic engagement. Washington, DC: Pew Internet \& American Life Project.

Lenhart, A., Madden, M. i Hitlin, P. (2005). Teens and technology: Youth are leading the transition to a fully wired and mobile nation. Washington, DC: Pew Internet \& American Life Project.

Levine, L.E. i Waite, B.M. (2000). Television viewing and attentional abilities in fourth and fifth grade children. Journal of Applied Developmental Psychology, 21, 667-679. doi:10.1016/S0193-3973(00)00060-5

Marini, Z.A., Dane, A.V. i Bosacki, S.L. (2006). Direct and indirect bully-victims: Differential psychosocial risk factors associated with adolescents involved in bullying and victimization. Aggressive Behavior, 32(6), 551-569. doi:10.1002/ab.20155

McDonald, D.G. (2009). Media use and the social environment. U: R.L. Nabi i M.B. Oliver (Ur.), Media processes and effects (str. 251-268). Los Angeles, CA: Sage.

Melchers, M., Li, M., Chen, Y., Zhang, W. i Montag, C. (2015). Low empathy is associated with problematic use of the internet: Empirical evidence from China and Germany. Asian Journal of Psychiatry, 17, 56-60. doi:http://dx.doi.org/10.1016/j.ajp.2015.06.019

Morahan-Martin, J. i Schumacher, P. (2003). Lonliness and social uses od the internet. Computers in Human Behavior, 19, 659-671. doi:10.1016/S0747-5632(03)00040-2

Mößle, T., Kleimann, M., Rehbein, F. i Pfeiffer, C. (2010). Media use and school achievement - boys at risk? British Journal of Developmental Psychology, 28, 699-725. doi:10.1348 /026151009X47S307

Nathanson, A.I. (2001). Parents versus peers: Exploring the significance of peer mediation of antisocial television. Communication Research, 28(3), 251-274. doi:10.1177/ 009365001028003001 
Nikken, P. i Jansz, J. (2004). Parental mediation of children's video game playing: A similar construct as television mediation. The Annual Meeting of the International Communication Association. New Orleans, LA: New Orleans Sheraton.

O'Neil, H.F., Jr., Wainess, R. i Baker, E.L. (2005). Classification of learning outcomes: Evidence from computer games literature. Curriculum Journal, 16(4), 455-474. doi:10. 1080/09585170500384529

Oliver, M.B., Kim, J. i Sanders, M.S. (2006). Personality. U: J. Bryant i P. Vorderer (Ur.), Psychology of entertainment (str. 329-341). Mahwah, NJ: Erlbaum.

Padilla-Walker, L.M., Coyne, S.M., Collier, K.M. i Nielson, M.G. (2015). Longitudinal relations between prosocial television content and adolescents' prosocial and aggressive behavior: The mediating role of empathic concern and self-regulation. Developmental Psychology, 51(9), 1317-1328. doi:10.1037/a0039488

Prot, S. i Gentile, D. (2014). Applying risk and resilience models to predicting the effects of media violence on development. Advances in Child Development and Behavior, 46, 215-244. doi:10.1016/B978-0-12-800285-8.00008-X

Rehbein, F. i Baier, D. (2013). Family-, media-, and school-related risk factors of video game addiction. A 5-year longitudinal study. Journal of Media Psychology, 25(3), 118-128. doi:10.1027/1864-1105/a000093

Roberts, D.F. (2000). Media and youth: Access, exposure, and privatization. Journal of Adolescence Health, 27, 8-14. doi:http://dx.doi.org/10.1016/S1054-139X(00)00128-2

Roberts, D.F., Foehr, U.G. i Rideout, V. (2005). Generation M: Media in the lives of 8-18 year-olds. Menlo Park, CA: The Henry J. Kaiser Family Foundation.

Robertson, J. i Howells, C. (2008). Computer game design: Opportunities for successful learning. Computers \& Education, 50(2), 559-578. doi:10.1016/j.compedu.2007. 09.020

Sanders, C.E., Field, T.M., Diego, M. i Kaplan, M. (2000). The relationship of internet use to depression and social isolation among adolescents. Adolescence, 35(138), 237-242.

Schmidt, M.E. i Vandewater, E.A. (2008). Media and attention, cognition, and school Achievement. The Future of Children, 18(1), 63-85. doi:10.1353/foc.0.0004

Shaw, L.H. i Gant, L.M. (2002). In defense of the internet: The relationship between internet communication and depression, loneliness, self-esteem, and perceived social support. Cyber Psychology \& Behavior, 5(2), 157-171. doi:10.1089/109493102753770552

Singer, J.L. (1980). The power and limits of television: A cognitive-affective analysis. U: P. Tannenbaum (Ur.), The entertainment function of television (str. 31-65). Hillsdale, NY: Lawrence Erlbaum.

Smith, S.W., Smith, S.L., Pieper, K.M., Yoo, J.H., Ferris, A.L., Downs, E. i Bowden, B. (2006). Altruism on American television: Examining the amount of, and context surrounding, acts of helping and sharing. Journal of Communication, 56, 707-727. doi:10.1111/j.1460-2466.2006.00316.x

Stipp, H. i Milavsky, J.R. (1988). U.S. television programming's effects on aggressive behavior of children and adolescents. Current Psychology: Research \& Reviews, 7(1), 76-92. doi:10.1007/BF02686665 
Subrahmanyam, K., Kraut, R.E., Greenfield, P.M. i Gross, E.F. (2000). The impact of home computer use on children's activities and development. The Future of Children, 10(2), 132-144. doi:10.2307/1602692

Subrahmanyam, K. i Lin, G. (2007). Adolescents on the net: Internet use and well-being. Adolescence, 42(168), 659-667.

Šincek, D., Tomašić Humer, J. i Duvnjak, I. (2015). Navike korištenja interneta i njihova uloga u doživljavanju neugodnih iskustava na internetu. U: M. Orel (Ur.), EDUvision 2015 "Modern Approaches to Teaching Coming Generations" (str. 143-156). Ljubljana: EDUvision.

Thomas, D. i Brown, J.S. (2009). Why virtual worlds can matter. International Journal of Learning and Media, 1(1), 37-49. doi:10.1162/ijlm.2009.0008

UCLA Internet Report (2003). Surveying the digital future, Year three. UCLA Center for Communication Policy. Preuzeto s http://images.forbes.com/fdc/mediaresourcecenter/ UCLA03.pdf

Valkenburg, P.M. i Cantor, J. (2000). Children's likes and dislikes in entertainment programs. U: D. Zillmann i P. Vorderer (Ur.), Media entertainment: The psychology of its appeal (str. 135-152). Mahwah, NJ: Erlbaum.

Valkenburg, P.M. i Peter, J. (2013). The differential susceptibility to media effects model. Journal of Communication, 63(2), 221-243. doi:10.1111/jcom.12024

Velki, T. (2012). Provjera ekološkoga modela dječjega nasilničkoga ponašanja prema vršnjacima. (Neobjavljena doktorska disertacija). Filozofski fakultet. Sveučilište u Zagrebu, Zagreb.

Verloigne, M., Van Lippevelde, W., Bere, E., Manios, Y., Kovács, É., Grillenberger, M., ... De Bourdeaudhuij, I. (2015). Individual and family environmental correlates of television and computer time in 10-to 12-year-old European children: The ENERGYproject. BMC Public Health, 15(912), 1-11. doi:10.1186/s12889-015-2276-2

Vrdoljak, G. i Velki, T. (2012). Metacognition and intelligence as predictors of academic success. Croatian Journal of Education, 14(4), 799-815.

Vulić-Prtorić, A. (2006). Skala hiperaktivnosti-impulzivnosti-pažnje-HIP. U: V. Ćubela Adorić, A. Proroković, Z. Penezić i I. Tucak (Ur.), Zbirka psihologijskih skala i upitnika III (str. 41-49). Zadar: Sveučilište u Zadru.

Weiss, M.D., Baer, S., Allan, B.A., Saran, K. i Schibuk, H. (2011). The screens culture: Impact on ADHD. Attention Deficit and Hyperactivity Disorders, 3(4), 327-334. doi:10.1007/s12402-011-0065-Z

Wilson, B.J. (2008). Media and children's aggression, fear, and altruism. The Future of Children, 18(1), 87-118.

Wright, K. (2001). Winning brain waves: Can custom-made video games help kids with attention deficit disorder? Discover, 22(3), 25-27.

Yoo, H.J., Cho, S.C., Ha, J., Yune, S.K., Kim, S.J., Hwang, J., ... Lyoo, I.K. (2004). Attention deficit hyperactivity symptoms and internet addiction. Psychiatry and Clinical Neurosciences, 58(5), 487-494. doi:10.1111/j.1440-1819.2004.01290.x 
Zill, N. (2001). Does Sesame Street enhance school readiness?: Evidence from a National survey of children. U: S.M. Fisch i R.T. Truglio (Ur.), "G" is for "growing": Thirty years of research on children and Sesame street (str. 115-130). Mahwah, NY: Lawrence Erlbaum Associates.

Zimmerman, F.J. i Christakis, D.A. (2005). Children's television viewing and cognitive outcomes: A longitudinal analysis of national data. Archives of Pediatrics and Adolescent Medicine, 159(7), 619-625. doi:10.1001/archpedi.159.7.619

\title{
Effects of Social Context on Correlation between Media Usage and Some Aspects of Children Development
}

\begin{abstract}
The aim of the study was to verify the relationship between the frequency of using different media (watching TV, playing computer games and browsing the Internet) with aspects of cognitive (academic achievement) and social-emotional development (impulsiveness, affective empathy, the number of friends and peer acceptance). The present study also investigated the moderating effects of the parental and peers presence on these relationships. Students from fifth to eighth grade $(N=880)$ completed the questionnaires about the impulsiveness, affective empathy and exposure to media. Students also gave information about the number of best friends, feeling of peer acceptance and academic achievement.

The results show low correlations between the frequency of using different media and aspects of cognitive and social-emotional development. Negative correlations with affective empathy, especially time spent playing computer games, and positive correlations with impulsivity, especially with Internet use, are most prominent. Correlations between the frequency of using media and number of friends and peer acceptance are somewhat weaker, while there is a mild negative correlation between time spent watching television and academic achievement.

The moderating effects of the social context on the correlation of the frequency of media use and aspects of development have been tested. The results show very small effects and they are mainly related to the relationship between watching television and academic achievement, and the frequency of playing computer games and relationship with peers.

There is a negative correlation between time spent watching TV and academic achievement, but only for those children who do so in the company (parents and friends) while for those who are watching TV alone the correlation doesn't significantly differ from zero. Likewise, the obtained positive correlation between the time spent playing computer games and the number of friends is somewhat smaller for those who do it in the company of friends and there are slightly positive effects of the frequency of playing computer games on peer acceptance for those who play alone, while the mildly negative effects are obtained for those who play with parents. All the effects of the social context and the use of media on the aspects of child development are of very low intensity and they are interpreted in accordance with the Differential Susceptibility to Media effects Model (DSMM; Valkenburg \& Peter, 2013).
\end{abstract}

Keywords: media, parental presence, peers, social-emotional development, cognitive development 


\section{Efectos del contexto social sobre la conexión entre el uso de los medios de comunicación y ciertos aspectos del desarrollo de los niños}

\section{Resumen}

El objetivo del trabajo fue verificar la conexión entre la frecuencia en el uso de diferentes medios de comunicación (ver la televisión, jugar a los vídeo juegos y navegar por internet) y los aspectos del desarrollo cognitivo (rendimiento escolar) y socio-emocional (impulsividad, empatía afectiva, número de amigos y aceptación entre coetáneos). Además, querían comprobarse los efectos moderadores de la presencia parental y compañía de amigos sobre dichas conexiones. En la investigación participaron 880 alumnos de la quinta a la octava clase. Los datos sobre la impulsividad, empatía afectiva y exposición a los medios de comunicación se obtuvieron a través de las autoevaluaciones. Los alumnos proporcionaron también datos sobre el número de amigos íntimos, sentimiento de la aceptación y rendimiento escolar.

La conexión entre la frecuencia en el uso de diferentes medios de comunicación y los aspectos del desarrollo cognitivo y socio-emocional en general es baja. Las más destacadas son las conexiones negativas con empatía afectiva, especialmente el tiempo usado para jugar a los vídeo juegos, tanto como conexión positiva con la impulsividad, en primer lugar, navegar por internet. En un grado menor se nota la conexión entre la frecuencia en el uso de diferentes medios de comunicación y el número de amigos y la aceptación entre coetáneos, mientras que la frecuencia en ver la televisión está un poco negativamente relacionada con el rendimiento escolar.

Se han evaluado también los efectos mediadores del contexto social sobre la conexión entre la frecuencia en el uso de los medios de comunicación y los aspectos de desarrollo. Efectos obtenidos son muy débiles y en mayor medida relacionados con el uso de la televisión y el rendimiento escolar, o con la frecuencia en jugar los vídeo juegos y la relación con los coetáneos. Se ha obtenido una conexión negativa entre el tiempo usado para ver la televisión y el rendimiento escolar sólo en aquellos que lo hacen en compañía (de padres y amigos), mientras que en aquellos que lo hacen solos no es significativamente diferente de cero. Además, la conexión positiva entre el tiempo usado para jugar a los vídeo juegos y el número de amigos es un poco menor en aquellos que lo hacen en compañía de amigos y los efectos de la frecuencia en jugar a los vídeo juegos sobre la aceptación entre coetáneos son ligeramente positivos en aquellos que lo hacen solos, mientras que son ligeramente negativos en aquellos que juegan en compañía de los padres. Todos los efectos del contexto social y el uso de los medios de comunicación sobre los aspectos del desarrollo de los niños son de una intensidad muy débil, y se han interpretado dentro del Modelo de la susceptibilidad diferente a la influencia de los medios de comunicación (DSMM; Valkenburg y Peter, 2013).

Palabras clave: medios de comunicación, presencia parental, coetáneos, desarrollo socioemocional, desarrollo cognitivo

Primljeno: 17.07.2016. 